\title{
Archaeological retrospect 6
}

\author{
GORDON R. WILLEY
}

\begin{abstract}
Gordon Willey is very properly regarded as the doyen of scholars working in American archaeology: his two-volume work, 'An introduction to American archaeology' (1966-71) was a significant landmark in the history of American archaeological research. He retired from the Bowditch Professorship of Archaeology at Harvard, which he held for 33 years, in 1982 and is now a Senior Professor there. For many years he has been a valued friend and advisor to this joumal. Here he describes his varied archaeological career which has embraced fieldwork and excavations in North America, Peru, Panama, and Central America. Without optimism archaeology would be impossible' he writes, 'we address the remote past with the confidence that eventually, by some means or other, we will come to understand it.' Here is prospect, as well as retrospect.
\end{abstract}

Although I am not altogether sure just how one's genealogy relates to one's career, let me begin that way. The history of my particular branch of the Willey family, at least on this side of the Atlantic, begins with three brothers, soldiers in the army of Lord Cornwallis who surrendered to the Americans at Yorktown. After a brief internment as prisoners of war, they chose to become citizens of the new republic in exchange for lands on its western frontiers. There was a generation-to-generation westerly movement, first Pennsylvania, then Ohio, and then Iowa. My grandfather, William Willey, settled in Iowa in 1855 , with a large farm holding in the Mississippi bottomlands. My father was born there in 1876 , the twelfth of ${ }_{3} 3$ children. Apparently, the farm property was not large enough to share among so many, so after two years at the agricultural school at Iowa State University, he decided to go into pharmacy. To continue with this genealogical sketch, his mother was of Scots descent; and on my mother's side my grandfather came direct from Scotland while my grandmother was from Amsterdam. To come to me, I was born on 7 March 1913 , in Chariton, a small county-seat town in southern Iowa, where my father was the moderately prosperous owner of a drug store. All this places me, I would assume, as a middle class 'wasp' from the middle of the middle class and the middle of the Middle West.

In $19^{2} 5$ my parents and I (an only child) moved to Long Beach, California, completing the westerly migratory track of the Willey family, although this time the journey was made in a Packard sedan rather than a covered-wagon. Our middle class, middle western ambience was not greatly changed, however, by this move to California for in those days Long Beach was considered a kind of 'Iowaby-the-Sea'. My father bought another drug store there, and I went to the public schools. In due time, I was to reverse the traditional westward movement of my forbears and start back east.

I have a very clear recollection of just when it was that $I$ decided to be an archaeologist. This was in the spring of 1929 when, in a high school English class, we were asked to write the usual essay on 'my intended career'. Previously, I had always disposed of such assignments by declaring my intention to be a writer, but this time I announced that I was going to be an archaeologist. As I think back, I knew almost nothing about the subject, but I believe my father had pointed me toward the idea, deriving whatever familiarity he had with archaeology from the popular press. Earlier, as I recall, he and I had both been fascinated by the Tut-ankh-amen discoveries.

I stuck with my choice of archaeology, and when it came time to go to college my mother supported me, although I think that by this time my father must have had his doubts. He would have preferred it if I had selected something more conventional, such as the law. The high school counsellor for guidance on college and university curricula, on learning of my desires, took down the catalogue for the University of California, at Berkeley, where I 
wanted to go and where many of my friends were going, but advised me, sadly, that there was no 'Department of Archaeology' at the institution. It was to be some years before I found that archaeology often was subsumed, variously, under the academic headings of anthropology, classics, or fine arts. When I did find this out, I was nonplussed to learn that Berkeley had a top-quality Department of Anthropology, with archaeological offerings, headed by a gentleman named A. L. Kroeber. At that moment, however, the counsellor brought down from her shelf the catalogue of the University of Arizona, another nearby seat of learning, and they did have a Department of Archaeology so I went off to Tucson, Arizona, in $193 \mathrm{I}$.

In reflecting back upon all of this, I sometimes wonder if my choice of a university at that time was really such a crucial decision. To be sure, I can say, rightly enough, that I decided upon archaeology as a career at a very early age; but I knew very little about the field, and, I am afraid, I did very little to really find out much about it, or to address myself very seriously to it until I was virtually finished with my undergraduate years. As a boy, I had had no interest in such pursuits as arrowhead collecting. Nor did it ever dawn on me that there might have been such a thing as California archaeology. It seems I was fired only by a rather shallow romanticism, by dreams of ancient Egypt or other far-off places.

As an undergraduate at Arizona, I was a reasonably good student and did well enough in the archaeology and anthropology courses offered by Professor Byron Cummings, the head of the department, and by Clara Lee Fraps and John Provinse; but I never became truly interested in the local Southwestern archaeology, and my teachers must often have despaired of my seriousness. I lived in a fraternity house and entered fully into the life there. I devoted a lot of time and effort in trying to become a track star. Every spring semester I missed a fair number of classes by being away on intercollegiate trips; and on late afternoons, when I should have been working in the museum laboratories, I was out running around the track. I remember it well because the windows of the pottery laboratory, which was housed under the athletic stadium, were on a level with the track, and I could see my more diligent student colleagues down there, working away, as I sped past. It always gave me a twinge of guilt. Besides this, I failed to participate in the summer field school excavations which were held each year in the White Mountains of Arizona. Instead, up until my last year, I went home to California each summer to spend my time ori the beach. In retrospect, I can only thank Professor Cummings for his patience with me in those years.

Fortunately, at least for my career in archaeology, I changed. I cannot pinpoint any single reason for, or event making, the change, but I suppose it had something to do with growing up. After graduation in 1935, I did go to the summer field school. This was at the Kinishba ruin, a Pueblo IV, Salado-affiliated site in the White Mountains, where Professor Cummings had a student group and also a crew of Apache Indian diggers. It was the first time I had ever done any sustained fieldwork in archaeology, and I enjoyed myself immensely and learned a lot. Toward the end of the summer, I talked with Professor Cummings about what I might do in the fall. Although I was beginning to know something about Southwestern archaeology, I was still enamoured of Egypt and the Near East so he advised me to write to the Oriental Institute at Chicago for admission there. I did this but was turned down so I returned to the University of Arizona for their M.A. graduate program.

In 1935 there were about a half-dozen of us in the graduate archaeological program. My most memorable activities for the year were participating in Cummings's seminar on Middle American archaeology, a field that captured my imagination as much as that of the Old World's ancient civilizations, working with Professor A. E. Douglass in dendrochronology, and writing a Master's dissertation on archaeological excavation methods. Considering my limited experience in the field, my decision to write a thesis on 'excavation methods' was a demonstration of the temerity of youth. I think the thing that prompted me to take up the subject was my restiveness in feeling that all archaeological courses were directed only toward the substantive aspects of prehistory. What were the 'principles' of the discipline? Rather naively, I thought that these might lie in 'how to dig'. I was not aware of problems in typology and classification, let alone those of culture change and process. Still, a review of digging techniques was not altogether a waste of time for a tyro. I tried to range world-wide in my survey although most of my data came from Southwestern archaeology. I learned how very little had been written on excavation 
procedures, per se, at that time. One of the profitable by-products of my research was visiting the Gila Pueblo research foundation at Globe, Arizona and talking with Emil W. Haury, fresh from the Snaketown excavations and emerging as the leading Southwestern archaeologist.

During the year, I had been thinking about the future, and I sought scholarships at other universities with advanced programs in anthropologyarchaeology. I tried again at the Oriental Institute; I looked for museum assistantships-all to no avail. Sometime in the spring, Professor Cummings called me into his office and gave me a notice of the Laboratory of Anthropology (Santa $\mathrm{Fe}$ ) Summer Field Fellowships in Archaeology, suggesting that I apply, which I did. Late in the spring, not long before my M.A. graduation, I received a letter from Santa Fe telling me that I had been selected as one of six students for their summer program. This was, indeed, a crucial turning point in my attempts to become a professional archaeologist. Small as the fellowship was, and it covered only the summer months of $193^{6}$, there was no other possibility open to me. If I had not received it I would have had to give up archaeology.

In June I left Tucson for Santa Fe, where I was to pick up the Laboratory of Anthropology station wagon and drive it back to Macon, Georgia, the scene of the summer excavations that year. Previously, the Laboratory of Anthropology Summer Archaeological Program had been staged at various places in the Southwest. This was the first time it was to be in another area, and I found the prospect particularly exciting. I knew nothing of Eastern United States archaeology; it was to be a completely new experience. Macon was the location of a Federal Relief (WPA) archaeological project which had been going since I933. The work there was centered at a large Indian mound group on the outskirts of that middle-sized southern city. The director of the project was Dr Arthur R. Kelly, a Harvard Ph.D. and a former professor of physical anthropology and archaeology at the University of Illinois. He had kindly consented to take on the Laboratory of Anthropology group for the summer and to integrate us into his ongoing operations. These operations were considerable. The relief rolls in Macon and surrounding territory were swollen in 1936 , the depths of the depression, and Kelly had several hundred men, armed with picks, shovels, and trowels, at his command. Many of these were concentrated on the Macon site proper; others were scattered around at various smaller archaeological sites in the county. At the beginning of the excavations, in I 933, Kelly had had James A. Ford as an assistant, but when the Laboratory of Anthropology group arrived in 1936 Ford was no longer there and Kelly had to rely on nonarchaeological help for his supervisors. Some of these were very good at their jobs, however, particularly two Georgia Tech-trained young engineers, of about our age, who gave us valuable instruction in the use of the transit, alidade, and plane table.

Our student group, except for myself, were all from eastern universities, Harvard, Yale, Columbia, and Pennsylvania. We were evenly distributed in anthropology's subdisciplines: J. B. Birdsell and Lawrence Angel in physical anthropology; Charles Wagley and H. Y. Feng, in ethnology; and Walter Taylor and myself, in archaeology. It turned out to be a most congenial crowd, and it was a real learning experience for us all. None of us had ever been in the deep south before, let alone to do archaeology there. There was some archaeological literature then on the southeastern United States-the writings of C. C. Jones, W. K. Moorehead, and C. B. Moore-but none of us was familiar with it so the mysteries of burial tumuli, platform mounds, and complicated stamped pottery rushed in upon all of us in a bewildering way. Unable to comprehend much of the culture history of the area, we, nevertheless, had many good arguments and discussions over the proper ways to excavate complex mound structures and properly expose burials. I was saddened to see the summer end. All of my colleagues were returning to graduate schools; only I had no place to go. Fortunately, and at the last minute, Dr Kelly agreed to take me on as his assistant. This was to be for both excavation work and also to explore the possibilities of developing a dendrochronological, or tree-ring, sequence for central Georgia. On the first of September, after a railroad station farewell to my summer friends, I entered upon my first job, employment in archaeology, complete with a salary, small as it was.

I stayed in Macon for two years. My dendrochronological work was confined to living trees. I was able to develop a ring sequence back to about $\mathrm{AD}$ 1800 , with a few 'checking rings or ring patterns', but the Georgia pines seemed too 'complacent' in their ring growths to make further investigations worthwhile. This research did allow me, however, to publish my first article (Willey, I937). In the 
spring of 1937, the National Park Service, with Civilizan Conservation Corp assistance, took over the Macon archaeological site which was renamed Ocmulgee National Monument; and Kelly, I, and the two Georgia Tech engineers were taken into the new administrative structure. I was given more duties as an excavation supervisor, and I began to learn about Southeastern pottery in a detailed way. In 1938, Dr Kelly was transferred by the National Park Service from Macon to Washington, DC. He was my first boss, and an extraordinarily kind and warm-hearted man. I was sorry to see him go. Fortunately, he was replaced by J. D. Jennings, a good archaeologist who became a good friend and who was kind enough to serve as best man at my wedding.

During 1937 and I938, James Ford visited Macon frequently, and, for a time, was employed by the National Park Service in restoring the Macon Ceremonial Earth Lodge. Ford had worked extensively in Mississippi and Louisiana archaeology and was very knowledgeable about Southeastern pottery. He, Preston Holder, who was doing WPA digging on St Simon's Island on the Georgia coast, A. J. Waring, Jr. of Savannah, and I, had numerous long discussions about Southeastern ceramic typo$\log y$.

In the fall of 1938 , I married Katharine Whaley, of Macon, and shortly thereafter we moved to New Orleans where I joined Ford in his WPA project in Louisiana archaeology. Katharine was neither archaeologist nor anthropologist, and it was in a social, rather than professional, context that we met. But she was no mean artist, and although she did not pursue her talent professionally she has, at various times, done some pen-and-ink work for me for archaeological illustrations. She also accompanied me on one expedition to Peru, two to Guatemala and two to Honduras. She helped with lab work, especially pottery restoration at which she has real skill, and also with drawings.

Ford and I had fieldwork going on at two locations, at the Crooks Mound, and the better known site of Marksville. W. T. Mulloy and Arden King ran the Crooks Mound operation, and R. S. Neitzel, the dig at Marksville. I was in charge of the New Orleans Laboratory, and Ford was the overall director. This experience continued to expand my knowledge of Southeastern archaeology, and particularly, Southeastern ceramics. Ford and I completed the manuscript on the Crooks Mound (Ford $\&$ Willey, 1940) by mid-1939, and were beginning on other writing projects, but after three years in the field in the Southeast, I felt that I should go back to graduate school.

Actually, I had tried each year to enter into graduate work somewhere, but I had been unable to secure the necessary scholarship aid. Perhaps it was just as well for I needed the field experience of those three years. But in 1939 my applications were at last successful, and I was offered tuition scholarships at both Columbia and the University of Chicago. The latter was in response to application to their Department of Anthropology, for by this time I had given up on Near Eastern archaeology. Having done real research in another part of the world, I was sufficiently engrossed with my new area to forget the lures of faraway places. I finally chose Columbia. The scholarship stipend was a little better, and Katharine knew New York. I began there in the fall of 1939 , with Duncan Strong as my major professor. He had come there only recently after a period at Nebraska where he had distinguished himself in Plains archaeology. His seminar that first year was in Southeastern United States archaeology, and I revelled in it. Albert Spaulding was a fellow student, and he, too, had come from Southeastern Federal Relief archaeology. As a follow up to that academic year, Strong arranged for Dick Woodbury and myself to spend the summer on a Florida coastal archaeological survey. That summer's work formed the nexus of my monograph, Archaeology of the Florida Coast (Willey, 1949), which came out a good many years later. In this Florida study, my previous experience in, and knowledge of, Georgia and Louisiana archaeology stood me in good stead.

One of the advantages of graduate school at Columbia was the proximity of the American Museum of Natural History and the anthropologists there. Both Harry Shapiro (physical anthropology) and George Vaillant (Middle American archaeology) taught in the department at Columbia, and I had courses with both. In I 94I, Vaillant was instrumental, through his friendship with Nelson Rockefeller, to arrange for a substantial sum to be contributed by Rockefeller's Office of the Coordinator for Interamerican Affairs to the Institute of Andean Research to do archaeology in Latin America. Ten projects were planned, reaching from Mexico down to Chile; and Strong, who had long been interested in Peru, was named to head one of the field parties for that country. He picked me for his assistant. After completing my doctoral 
examinations that May, Katharine and I, along with Junius and Peggy Bird, who were bound for a similar mission in Chile, sailed from New York on the Grace Line's SS Santa Elena in early June. At last I was to have the opportunity to see a 'high culture' at first hand, not Mesopotamia nor Mesoamerica, but something that sounded almost as good, Peru.

Duncan, Junius, and I surveyed the Peruvian coast for two weeks until Junius and Peggy resumed their journey to Chile; then we were invited by J. C. Tello, Peru's leading prehistorian, to dig at Pachacamac. Pachacamac, not far south of Lima, is one of Peru's great ruins. It was a pilgrimage shrine of the Inca when the Spanish first entered the country, but it had a much longer history, or prehistory, as Max Uhle $(19 \circ 3)$ had demonstrated almost 40 years before our arrival there. Our goal, as Strong had explained to Tello, was refuse-heap stratigraphy. Uhle and Kroeber had made a good beginning in developing an archaeological chronology for Peru from stylistic seriations of grave lot pottery, but we felt this could be improved upon, or at least greatly augmented, by potsherd stratigraphy which would refine the chronology and also expand our knowledge of Peruvian pottery beyond the fancier funerary ceramics. Tello advised us that if we were looking for refuse heaps, he knew just the place. He took us out to Pachacamac, where his own excavation crews were working at another part of that vast site, and showed us a great, shaggy-looking, grey-black pile situated on a slope below the pyramid known as the Inca 'Temple of the Sun'. With a small crew of workmen, we began a test trench in this 'haystack' on the following day. I use the word 'haystack' advisedly for beneath a few centimetres of surface dust we began cutting through a firmly packed mass of maize stalks, other vegetal fibres, peanut shells, scraps of textiles, and miscellaneous, semidecayed debris. The Peruvian rainless coast is known for such remarkable preservation, and to some extent the degree of preservation, or the lack of it, is a rough clue to the relative age of a deposit. Our 'haystack' was purely Imperial Inca, probably no more than 500 years old. To one who had known only North American archaeology, this kind of preservation of prehistoric materials was almost too much to contend with. I will never forget the day when one workman, having injured his bare foot slightly, pulled a textile fragment out of the profile to use as a bandage. The Inca debris turned out to be several metres thick. It was underlain by a light coloured, dusty soil through which we continued to dig. The sherds from these depths were radically different from those of the Inca dump and pertained to what Uhle had called the 'Interlocking Fish or Serpent' painted style, representative of an archaeological culture that he had identified as being pre-Tiahuanaco. So far, so good, we had pottery stratigraphy. It was hardly a chronological breakthrough, but, nevertheless, in the lowermost pottery-bearing levels of the Interlocking style refuse we noted certain differences in the pottery, and in the frequency counts among the various types, that offered suggestions of where we might do some further digging on the Peruvian coast.

Strong returned to the States in September of that year, leaving me to carry on the work in Peru. In this, I was joined by John Corbett, another young archaeologist, and one who had been working in Ecuador, and by Marshall Newman, a physical anthropologist who was a part of the Institute of Andean Research program in Peru. But to return to ceramic chronology on the Peruvian coast, I had been reading accounts of Uhle's work in the Chancay Valley (in Kroeber, 1926), a short distance to the north of Lima, and it struck me that stratigraphic procedures might help clear up the relationship between the Interlocking style, as found in that valley, and another style known as the 'White-on-red'. Uhle had argued that the Interlocking style was the earlier of the two, but his line of reasoning for this had not been a strong one. In the Pachacamac excavations, we had noted that there were a few White-on-red sherds mixed in with the lower Interlocking style levels. With this hint in mind, I shifted our operations to the Chancay and to Uhle's old site of Cerro Trinidad. This was a complex of adobe structures and refuse whose considerable depths were indicated by the road cut of the Panamerican Highway. For our stratigraphic purposes it proved a good choice. We were able to demonstrate that the White-on-red style was definitely the earlier of the two. Not long after this, Kroeber visited Peru, and I could proudly show him my results, with which, after reviewing the material, he concurred. Later, I used these Chancay data as the core of my doctoral dissertation (Willey, I943).

Corbett, Newman, and I went up to Puerto de Supe after Chancay, still following in Uhle's footsteps, this time to pursue the problem of Chavínoid-appearing pottery which he had found 
there many years before (in Kroeber, 1925). We made some significant Coastal Chavin finds there, including one amazing textile, and the Chavínoid theme also was central to our efforts in subsequent digging in the shell heaps at Ancon (Willey \& Corbett, 1954). One of the highlights of the Ancon excavations was a visit to the site by Uhle himself. The veteran Peruvianist had been attending an International Congress of Americanists meeting in I 939 and had been trapped in the country by the outbreak of World War II. Well into his eighties, Uhle spent half a day with us at Ancon, photographing the scene of his old activities and discussing pottery styles.

But it was at Supe that we failed to make an important discovery. We excavated for some days at the Aspero site there. Aspero turned out to be a large preceramic midden-something that we were totally unprepared for and found difficult to adjust to. At that time there was no Peruvian 'preceramic period'. Although we found other artifacts in the black, ashy refuse, and even excavated some dwelling structures, we missed, as had Uhle before us, the presence of artificial platform mounds at the site. I looked right at them, concluded they were natural landscape features, and failed to test them (Willey \& Corbett, 1954). It was not until years later, in 1971-well after the 'preceramic horizon' had become an established fact of Peruvian archaeology - when on a survey trip with a former student, M. E. Moseley, that I realized what I had missed at Aspero. This was after Moseley had shown me small artificial mounds at Rio Seco, a well-known preceramic site some kilometres south of Supe. I told him then that we had better continue our drive on up the coast and have another look at Aspero. Moseley confirmed my suspicions, especially when he followed up our trip with the later excavation of some of the Aspero mounds (Moseley \& Willey, 1973). It is an excellent case of not being able to find something if you are not looking for it. By 1971, it had become common Peruvian archaeological knowledge that artificial mound structures were a part of the Peruvian Coastal Preceramic. Thirty years earlier, the idea was unthinkable, and I rejected it. I relate this without any sense whatever of crying mea culpa. After all, archaeology is dodgy stuff. Anyone who insists on a record of infallibility is probably trying to fool others and definitely fooling himself.

We returned to the States in May of 1942. The following fall I completed my doctorate and taught for a year (1942-43) at Columbia. In the fall of 1943 I went to the Bureau of American Ethnology in the Smithsonian Institution, in Washington, DC, to be Julian Steward's assistant on the editing of the Handbook of South American Indians. Steward, at that time in his early forties, was clearly one of America's leading anthropological theorists. He had already shown this in previous papers in North American ethnology, and he was to bloom forth in some of his long essays in the Handbook (Steward, 1948, 1949a). The education in archaeology and anthropology, which I had begun with Cummings, Kelly, Ford, and Strong, was to be continued in this association with him. Together with Wendell Bennett we planned the Viru Valley program in late I 945 and, with additional colleagues, put it into operation in early 1946 .

As other young American archaeologists of my generation raised up in the academic house of anthropology, I had always been somewhat awed by my ethnological and social anthropological professors and colleagues. These were the people who controlled the core of theory, and, unwittingly or not, they let us feel that archaeology was something second rate. I can understand that contemporary European prehistorians, Classical scholars, Egyptologists, and Near Eastern archaeologists did not have this same kind of experience, but it was a part of the life of an Americanist archaeologist trained in a department of anthropology. To be sure, Kroeber had time for archaeologists, and did archaeology himself, and even the American 'father' of anthropology, Franz Boas, gave archaeology his occasional blessing; but, by and large, archaeologists did not have a high intellectual rating on the American scene. Clyde Kluckhohn, a leading anthropological theoretician of the I940s and I950s, scolded them (Kluckhohn, I940); but Julian Steward began a dialogue with them, and I was one of the first archaeologists to come under his influence.

Steward had done some archaeology, in the North American Great Basin where he also worked as an ethnologist, but he was certainly not primarily an archaeologist. He had a strong culture evolutionary orientation, and in his attempts to achieve an overview grasp of the multitudinous South American Handbook data, both ethnographic and archaeological, he leaned in this direction ever more strongly. At the same time, he was uncomfortable with evolutionary thinking in the abstract. He wanted to explore and compare the diverse lines of 
culture history (Steward, 1949b). It was in my many long discussions with Steward that he turned me toward settlement archaeology and, specifically, to the settlement pattern study in the Viru Valley. It should be made clear, however, that the study, as it eventually appeared (Willey, r953), was entirely my own designing. This is not said to detract from Steward's influence, but after the gathering of the field data in 1946 , under his very general guidelines that archaeologists should stop being so single-site oriented, and should try to see man's adaptations to natural and social environments over wider landscapes, I was left on my own. Steward departed from the Smithsonian in that same year for a professorial career, first at Columbia and then at the University of Illinois, and I had no further opportunities to discuss the 'settlement pattern approach' with him, especially during the years (1950-5I) in which I wrote most of the Viru report. Perhaps I would have done a better job if I had had his counsel, but, instead, I went ahead on my own with no very clear intellectual inspiration beyond what he had given me at the outset. I have already offered one 'retrospect' on this (Willey, 1974) and will say no more about it here.

Most of my writing time in the last years before I left the Bureau of American Ethnology was taken up with completing the long, compendium-like report on Florida archaeology, to which I have already referred (Willey, I949). In I949, I was offered the Bowditch Professorship at Harvard, although my colleagues there allowed me to stay on an extra year in the Smithsonian to complete some obligations with that institution.

When I went to Harvard, in the fall of $195^{\circ}, \mathrm{my}$ only Central American experience had been a season in Panama with my boss at the Bureau of American Ethnology, Matt Stirling. With this background experience, I wanted to return to Panama and did so in $195^{2}$, taking along two Harvard graduate students, C. R. McGimsey and James East. We excavated mainly at the Monagrillo shell mound site, where I had made a beginning in 1948, and the Monagrillo report was published by the Peabody Museum at Harvard (Willey \& McGimsey, 1954). It had been my intention to return to Panama for still a third season in 1953. I must have had some vague idea in mind of advancing upon the ancient civilizations of Mesoamerica by a gradually creeping process from the south. But A. M. Tozzer, my distinguished predecessor at Harvard, disagreed with this scheme in no uncertain terms. He had been patient while I did my first Harvard fieldwork in Panama, but he told me that it was my duty to gather up my courage and go direct to the Maya area. To be sure, the Bowditch Will, establishing the Bowditch Professorship, had said that 'Mexico and Central America' were to be the purview of the holder of the chair; but, according to Tozzer, Charles P. Bowditch, who had been his patron, and whose spirit was still supervising our activities, meant the Maya, and there were no two ways about it. I bowed to higher wisdom-in retrospect a very good decision on my part--and made preparations for a frontal attack on Maya archaeology.

I think it would be fair to say that Maya archaeology was then the most august field in Americanist studies. It had a long and rich tradition. The great, jungle-shrouded ruins themselves had a certain mystique. A host of distinguished scholars-hieroglyphic experts, students of art and iconography, and, in more recent years, architectural and ceramic specialists-had devoted lifetime careers to the Precolumbian Maya. Not only was Tozzer watching me from the office just across the hall, but there were A. V. Kidder, J. Eric Thompson, and others of the Carnegie Institution archaeological staff--Maya archaeologists allkeeping an eye on me from the Carnegie quarters next door to the Peabody Museum. I thought it would be the better part of valour to lead from what strength I had. I launched a settlement pattern project in the Belize Valley at a place called Barton Ramie. The location was decided upon because of extensive agricultural clearings which had revealed hundreds of small ruin mounds, putatively 'house mounds', along the river flats. I had seen these mounds in a preliminary scouting trip in 1953. In 1954, I was fortunate enough to receive the first grant for archaeological work ever given by the newly founded National Science Foundation; and, accompanied by graduate students William Bullard and John Glass, we began our mapping and excavations in February of that year.

There had been some incidental concern with settlement patterns in the Maya Lowlands, going back to Ricketson's Uaxactun surveys (Ricketson \& Ricketson, 1937); and the Carnegie archaeologists had conscientiously mapped all the residential mounds within the walled city of Mayapan (Pollock, et al, 1962 ; see also Ashmore \& Willey, r 981 ); but our Barton Ramie effort was the first to consider both localized distributions of residential 
and other mound structures ('micro-patterns') and larger geographic scale distributions and arrangements of site hierarchies (Willey, et al, 1965). We were lucky at Barton Ramie; the modern agricultural clearings had done some of our job for us. For the most part, dense jungle covers the Lowland and its archaeological sites, especially the small ones. At that date, air photography had been of little help although it was to be in the future. When I initiated my next Maya programme, at Altar de Sacrificios, in the Guatemalan Peten, wide-scale survey was carried out only with difficulty. The site's ceremonial centre was located on what was, in effect, an island in a jungle swamp. Relatively few residential mounds were found in its immediate vicinity. Presumably, Altar's sustaining populations had been located all along the Pasion and Salinas Rivers, extending for several kilometres in several directions from the ceremonial centre. Even now we have no real knowledge of the Pasion-Salinas settlement distributions; it remains as a task for future archaeologists to assemble this information (Willey, 1973). At Seibal, farther upstream on the Pasion, where we surveyed and excavated after the work at Altar de Sacrificios, we were on higher ground, and a 5 by $5 \mathrm{~km}$ block was laid out around the main site centre and carefully examined for structures of all types (Willey, et al, 1975). Many of these were excavated, and the forthcoming monograph on this, by Gair Tourtellot III, will take its place, along with similar studies from Tikal, Dzibilchaltun, Cobá, and elsewhere, as a major Maya settlement contribution.

Our labours at Altar de Sacrificios and Seibal lasted for ten field seasons, from r 959 until i 968 . For the whole time, A. Ledyard Smith, an old Maya hand from the Carnegie Institution's archaeological staff, and a brilliant architectural excavator, served as my field director. He not only directed much of the work but was in complete charge of setting up and maintaining our field camps. He has also written important monographs on the work at Altar and Seibal (Smith, 1972, 1982). Several graduate students-John A. Graham, R. E. W. Adams, Frank Saul, J. A. Sabloff, and Gair Tourtellot derived doctoral dissertations from their work at these two sites; and many other Mayanists, now distinguished in the field, such as E. W. Andrews, V, Ian Graham, Norman Hammond, and Arthur Miller, served on our staff.

My most recent fieldwork, and probably my last, was in Honduras. For a long time I had wanted to go into the north-eastern part of that country, one of the last regional archaeological blank spots of Central America; but, after some preliminary excursions, the attempt was aborted when the Honduran government refused to issue me an excavation permit. Some results eventually came out of the venture, however, in that Paul Healy, who had been my student assistant, was able to go back in subsequent seasons when he obtained permission to dig. He has since brought out some of the results (Healy, 1974, 1975). Then, in 1975 , the Hondurans invited me to begin a settlement pattern survey in the environs of Copan, in the southwestern part of that country. This was carried out in 1975 through 1977 , with Richard Leventhal and William Fash as my assistants (Willey, Leventhal, $\&$ Fash, 1978). Since then, this survey has been continued under Honduran governmental auspices by Claude Baudez and William Sanders.

This fieldwork chronicle, while certainly summarizing an important part of my career, has not been all of my life as an archaeologist. I have said little of my base, the Peabody Museum and the Department of Anthropology at Harvard University, where I have been for a third of a century. The associations I have had there, with archaeologists of many different interests, as well as with members of other branches of the anthropological family, have been important stimuli for all aspects of my work. It was with Philip Phillips, whom I had first known in the context of Southeastern United States archaeology, that I wrote Method and theory in American archaeology (1958). My students at Harvard have been equally significant in my development as an archaeologist. I am too old-fashioned to hold with the modern saying that the professor always learns as much from the student as the latter from the former; but, in my own case, this has been true on occasion. I have already mentioned some of these students, in connexion with the field programs, and there have been a host of others of high quality. Both graduate and undergraduate teaching led me to produce a two-volume work, An introduction to American archaeology ( $1966-7 \mathrm{I})$, which, incidentally, was actually written on two leaves which I spent in Cambridge, England. I enjoyed my stay there in many ways, especially my associations with Geoffrey Bushnell, Grahame Clark, and Glyn Daniel. It was Daniel who asked me to write A history of American archaeology (I974), which I completed with Jeremy Sabloff.

In looking back over what I have written here, I 
am afraid I have not been very explicit about what I think about archaeology. What is my theoretical stance? I am not sure that I can answer this in any very succinct way. Fifty years in archaeology-as a student, a practitioner, and a professor-have left me with the feeling that it is a very difficult discipline: fascinating, to be sure, but difficult. This does not mean that I am no longer optimistic about it. Indeed, without optimism archaeology would be impossible: we address the remote past with the confidence that eventually, by some means or other, we will come to understand it. It is when one tries to set down unchallengeable guidelines for doing this that the difficulties arise.

I do not know if we will ever come up with any processual or behavioural 'universals' in archaeology or not. If so, I have no very clear idea as to just what form these might take. I will remain hopeful; but, meanwhile, the best advice I could offer would be that the archaeologist must be immersed in the culture-historical contexts pertinent to the problems at hand. This may seem a commonplace; and some would say: 'We take this for granted; we are now ready to go beyond simple data control.' I can only reply that we are never really able to go beyond such control for problems, questions, and hypotheses are inextricably enmeshed in the data of history.

A second suggestion may seem the opposite of what I have just said. This is that the archaeologist, whatever the specific historical context in which he or she is working, will be better prepared to deal with the specific in the light of knowledge about other culture-historical contexts. Clearly, no one can be a 'world archaeologist', at least not on the level of front-line research. Still, knowledge of other areas, of other cultures than the one under primary study, gives one insights into one's own archaeological bailiwick. In other words, the advice is to be comfortable with a comparative point of view, with the anthropologist's cross-cultural perspective. And this applies not only to other archaeological cultures but to the resources of written history and ethnography.

Finally, and most controversially, while I am offering advice, I would recommend approaching causality with caution. Do not be faint of heart, but at the same time, remember that the search for cause seems to have a way of channelling one's outlook, of convincing the searcher that one approach, one basic philosophy has all the answers. There is an unavoidable tension in archaeological research, a tension between the material remains we study and our attempts to grasp the ideas which once created, shaped, and arranged these remains. This is a tension the archaeologist must learn to live with as he goes about trying to resolve it.

\section{B I B LIOG RAPHY}

ASHMORE, W. \& G. R. WILLEY. 198I. A historical introduction to the study of Lowland Maya Settlement Patterns, (ed.) Wendy Ashmore, Lowland Maya Settlement Patterns, 3-19.

FORD, J. A. \& G. R. WILley. 1940, Crooks Site: A Marksville Period burial mound in LaSalle Parish, Louisiana. Anthropological Study 3, Department of Conservation, Louisiana Geological Survey (New Orleans).

healy, P. F, 1974. The Cuyamel Caves: Preclassic sites in Northeast Honduras, American Antiquity, xxxix, No. 3 , $435^{-47}$.

HEALY, P. F. 1975. H.CN-4 (Williams Ranch Site): Preliminary Report on a Selin Period site in the Department of Colon, Northeast Honduras, Vinculos, I, No. 2, 61-102.

кцUскнону, с. 1940. The Conceptual structure in Middle American studies. The Maya and their neighbors (New York).

KROEBER, A. L. 1925. The Chle pottery collections from Supe. University of California Publication in American Archaeology and Ethnology, Vol. 21, 235-264.

KROEBER, A, L, 1926. The Uhle pottery collections from Chancay. University of California Publications in American Archaeology and Ethnology, Vol. 21, 265-304 (Berkeley).

MOSELEY, M. E. G. R. WiLley. 1973. Aspero, Peru: A reexamination of the site and its implications, American Antiquity, xxxvin, No. 4, 452-68.
POLLOCK, H. E. D., R. L. ROYS, T. PROSKOURIAKOFF \& A. L. SMITH 1962. Mayapan, Yucatan, Mexico. Carnegie Institution of Washington, Publications No. 619 (Washington, DC).

RICKETSON, O. G., JR. \& E. B. RICKETSON. 1937. Uaxactun, Guatemala Group E-1926-1931. Carnegie Institution of Washington, Publication No. 477 (Washington, DC).

Smith, A. L. 1972. Excavations at Altar de Sacrificios: architecture, settlement, burials, and caches, Peabody Museum Papers, Vol. 62, No. 2, Harvard University, Cambridge, MA.

1982. Excavations at Sejbal: Major architecture and caches, Memoirs, Peabody Museum, Vol. 15, No. I, Harvard University, Cambridge, MA.

STEWARD, J. H. 1948. The Circum-Caribbean tribes: an introduction. In (ed.) J. H. Steward, Handbook of South American Indians, 1-42, Bureau of American Ethnology, Smithsonian Institution, Bulletin I43, Vol. 5 (Washington, DC).

1949a. South American Cultures: an interpretative summary, Handbook of South American Indians, Vol. 5, 669-772, Bureau of American Ethnology, Bulletin 143, Smithsonian Institution (Washington, DC).

ro4gb. Cultural causality and law: a trial formulation of the development of early civilizations, American Anthropologist, LI I-27 (Menasha, Wisconsin). 
Uhle, M. 1903. Pachacamac. Department of Archaeology, University of Pennsylvania, Philadelphia, PA.

Willey, G. R. 1937. Notes on Central Georgia dendrochronology,

Tree Ring Bulletin, Vol. 4, No. 2, University of Arizona, Tucson.

1943. Excavations in the Chancay Valley, in Archaenlogical Studies in Peru, by W. D. Strong, G. R. Willey, \& J. M. Corbett, Columbia University Studies in Archaeology and Ethnology, Vol. 1, No. 3, Columbia Lniversity Press, New York.

1949. Archaeology of the Florida Gulf Coast, Smithsonian Miscellaneous Collections, Vol, I13, Smithsonian Institution, Washington, DC.

1953. Prehistoric settlement patterns in the Viru Valley, Peru. Bulletin 155 , Bureau of American Ethnology, Smithsonian Institution, Washington, DC.

1973. The Altar de Sacrificios Excavations, General Summary and Conclusions, Peabody Museum Papers, Vol. 64, No. 3 , Harvard University, Cambridge, MA.
1974. The Viru Valley settlement pattern study, in (ed.) G. R. Willey, Archaeological Researches in Retrospect, 149-79, Winthrop Publishers, Inc., Cambridge, MA.

WILLEY, G. R., W. R. BLLLARD, JR., J. B. GLASS, \& J. C. GIFFORD 1965. Prehistoric Maya Settlements in the Belize Valley. Peabody Museum Papers, Vol. 54, Harvard University, Cambridge, MA.

WILLEY, G. R. AND J. M. CORBETT. 1954. Early tincon and Early Supe Culture: Chaz in Horizon Sites of the Central Pencian Coast. Columbia Studies in Archaeology and Ethnology, Vol. 3, Columbia University Press, New York.

WILLEY, G. R., R. M. LEVENTHAL \& W. L. FASH, JR. 1978. Maya Settlement in the Copan Valley, Archaeology; xxxi, No.4, $32-44$.

WILley, G. R. \& C. R. MCGIMSEY. 1954. The Monagnilo Culture of Panama. Papers, Peabody Museum, Harvard Liniversity, Vol. 49, No. 2. Cambrige, MA.

\section{Book Chronicle}

We include here books which have been received for review, or books of importance (not received for review) of which we have recently been informed. We welcome information about books, particularly in languages other than English, of interest to readers of ANTIQUITY. The listing of a book in this chronicle does not preclude its review in ANTIQUITY.

Wasy Greckie. II. Attycka ceremika czerwonofigurowa by Witold Dobrowolski. Warsaw: National Museum, 1982.56 pp., 23 pls.

The Celts by T. G. E. Powell, London: Thames $\xi^{\circ}$ Hudson, 1983 (paperback reissue with preface by Stuart Piggott). 232 pp., 137 b/willus., 12 colour. $£ 4.95$.

Palaeoecology of Beringia edited by David M. Hopkins et al. New York, London, Paris: Academic Press, 1983.504 pp., many illus. \$37.00.

Abu Salabikh Excavations, Vol. 1. The west mound surface clearance by J. N. Postgate. London: British School of Archaeology in Iraq, 1983.120 pp., 12 pls., 353 figs.

Le néolithique et le bronze ancien égéens: les problèmes stratigraphiques et chronologiques, les techniques, les hommes by René Treuil. Paris: Ecole Française d'Athènes, 1983 (distributed by De Bocard, 11 Rue de Médicis, 75006 Paris). 562 pp., 7 pls., many figs.

Archaeology of the dreamtime: the story of aboriginal Australia and its people by Josephine Flood. London: Collins, 1983. 288 pp., many figs., 27 b/w pls., 13 colour pls. $£ 13.95$

The Thetford Treasure: Roman jewellery and silver by Catherine Johns and Timothy Potter. London: British Museum Publications, 1983.136 pp., 45 figs., 16 b/w pls., 14 colour pls. $£ 27.50$.
Cycladic Art: the N. P. Goulandris collection by Christos Doumas. London: British Museum Publications, 1983. 166 pp., many illus. £7.95.

Ceramics, chronology, and community patterns: and archaeological study at Moundville by Vincas P. Steponaitis. Studies in Archacology Series. New: York, London, Paris: Academic Press, 1983. 396 pp., 67 figs.

Roman London by Peter Marsden. London: Thames $\mathbb{F}^{\circ}$ IIudson, 1983 (paperback reissue). 224 pp., 160 illus. f.9.95.

Excavations at Carn Brea, Illogan, Cornwall 19701973. A neolithic fortified complex of the 3rd millennium be by Roger Mercer. Cornish Archaeology 20 ( I $98 \mathrm{r}$ ), I 983.204 pp., 75 figs., 28 pls.

Pharaoh triumphant: the life and times of Ramesses II by K. A. Kitchen. Warminster: Aris \& Phillips, 1983. 280 pp., 78 illus. £12.50.

The Asturian of Cantabria : Early Holocene HunterGatherers in Northern Spain by Geoffrey A. Clark. Anthropological Papers of the University of Arizona, 41. Tucson: University of Arizona, 1983. 184 pp., many figs. $\$ 18.95$.

Notes on Late Egyptian grammar: a semitic approach by A. M. Bakir. Warminster: Aris $E^{\circ}$ Phillips, $1983.156 \mathrm{pp}$. £10.00.

continued on p. 24 


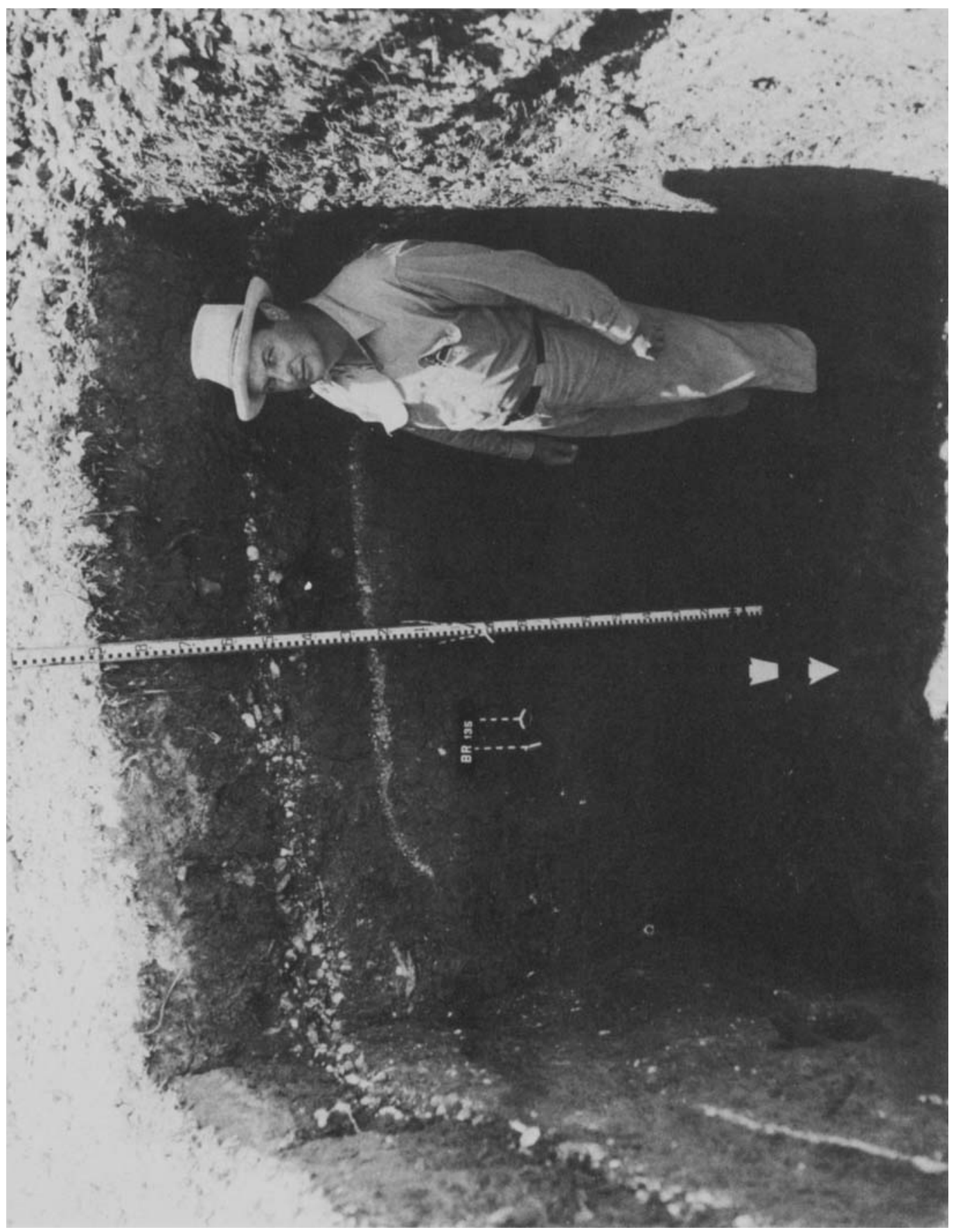

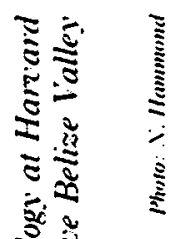

$\frac{2}{2}$

范

)

ธิ

政

si

8

ป

งิ

ธี

.

- इ

+ วิ

(1)

(2)

क ह

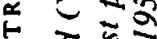

๙

$\because \quad \approx$

$\Xi$ छ $\Xi$

क

出

ذ ठิ

a

包

है

5

I

I)

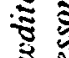

ปั้

20

ㄴ.

蛋

खें

:

달

ริ

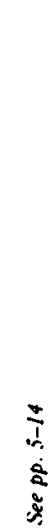

